\title{
Faculty Perceptions of Online Teaching at a Midsized Liberal Arts University
}

\author{
Dana L Shreaves \\ Pacific Lutheran University \\ Yu-Hui Ching, Lida Uribe-Florez, and Jesús Trespalacios \\ Boise State University
}

\begin{abstract}
In this mixed-methods study, faculty perceptions of online teaching at a midsized liberal arts university were examined to better understand faculty acceptance and participation in online teaching at the university. Seventy-nine participants responded to a survey that collected qualitative and quantitative data. Content analysis of faculty perceptions of online teaching was employed and resulted in the identification of six themes. An examination of 21 quantitative factors identified 17 factors reported by more than $50 \%$ of respondents to influence their decision to teach or not teach online. Study participants perceived online learning as attractive to students but they wanted any online courses carefully regulated, in part because online learning was seen as contrary to their teaching values. Participants were influenced by personal preferences but also the desire for robust faculty resources, as well as more effective technology and infrastructure. Implications and directions for future research were discussed.
\end{abstract}

Keywords: online teaching, liberal arts, faculty perceptions, incentives, barriers, mixed methods, survey

Shreaves, D.L., Ching, Y.-H., Uribe-Florez, L., \& Trespalacios, J. (2020). Faculty perceptions of online teaching at a midsized liberal arts university. Online Learning, 24(3), 106-127. https://doi.org/10.24059/olj.v24i3.2199

\section{Faculty Perceptions of Online Teaching at a Midsized Liberal Arts University}

Education is evolving from the influence of technology. This trend is especially evident in the field of online education. While campus enrollments in higher education have declined across the United States, online learning has shown steady or increasing growth (Seaman et al., 2018). However, many faculty members who teach in higher education have resisted the idea of teaching online and view online education with fear or disdain (e.g., Allen \& Seaman, 2015; Allen et al., 2012; Mitchell et al., 2015; Vivolo, 2016). Researchers have examined issues affecting faculty participation in online education. Nevertheless, faculty acceptance of online education has 
remained unchanged at an acceptance rate of only 30\% (Allen \& Seaman, 2015). If online education is to succeed in an institution, the faculty must accept and participate in online teaching (Schopierary, 2006).

For institutions looking to offset the revenues lost from declining enrollments, online learning offers an opportunity for new revenue sources. Despite substantial research on the benefits afforded by learning online, institutions of higher education continue to observe faculty resistance to teaching online (Mitchell et al., 2015; Vivolo, 2016). To recruit and retain online instructors, institutions must understand the issues that affect the faculty's willingness to teach online. Little research has been conducted to specifically examine the perceptions of online education among liberal arts faculty, who may resist attempts to change the instructional practices that have traditionally formed the foundation of a liberal arts education. Therefore, the purpose of this study was to examine how faculty perceived online teaching at a midsized liberal arts university in order to understand faculty acceptance and participation in online teaching at the university. This study was guided by the following research questions:

1. How do faculty perceive online teaching and learning at a liberal arts university?

2. What factors are reported to affect faculty's decision to teach or not teach online at a liberal arts university?

\section{Review of Relevant Literature}

\section{Liberal Arts Teaching}

Researchers on liberal arts education (Deneen, 2014; Thompson, 2015; Wells, 2016) noted the tension between faculty's desire to survive during times of change and the desire to maintain the distinct characteristics that liberal arts education has cultivated for over a hundred years. Clark (1987) described stark differences in the academic life of faculty in research universities, liberal arts colleges, and community colleges. Clark (1997) noted that faculty in middle-level, liberal arts colleges often claimed their relationships with students were highly valued in their careers as academic professionals. Faculty who have chosen to teach at a liberal arts institution may be especially resistant to attempts to change their pedagogical practices (Baker \& Baldwin, 2015) and could perceive online teaching as threatening or outright incompatible with their teaching practices. Therefore, it is important to study faculty perceptions of online teaching at liberal arts institutions to better understand the unique perspectives of this demographic.

\section{Factors Influencing Faculty Participation in Online Teaching}

When analyzing factors that affect faculty members' perception of online teaching, some researchers broadly grouped these variables into two categories: (1) encouraging factors, also called incentives, bridges, or motivators, and (2) discouraging factors, also called obstacles, barriers, or de-motivators (Bacow et al., 2012; Berge, 1998; Haber \& Mills, 2008; Herman, 2013; Maguire, 2005; Shea, 2007).

\section{Factors that Encourage Online Teaching}

Five categories of factors that encourage online teaching are: personal challenge and satisfaction, flexibility and convenience, greater student access, unique instructional options, and institutional rewards and recognition. Faculty may be energized by the opportunity to grow personally and professionally through learning new technology and teaching skills (Shea, 2007). 
Professional development for online teaching can enhance faculty's face-to-face teaching as well as their confidence, motivation, and attitudes towards online learning (Borup \& Evmenova, 2019). The flexibility afforded by asynchronous online teaching and the possibility of reaching a wider audience of learners can be an incentive for faculty to teach online (Allen \& Seaman, 2008; Maguire, 2005; Schopieray, 2006; Shea, 2007; Wasilik \& Bollinger, 2009). Another key motivator for many faculty is the ability to teach any time or place, which may improve work-life balance or allow more opportunities for research, travel, or family care (the most important motivator that encouraged faculty in their studies to teach online was the ability to teach any time or place that allow faculty to improve their work-life balance or incorporate more opportunities for research, travel, or family care (Hiltz et al., 2007; Shea, 2007). .

Faculty may be motivated by the possibility of using new, technology-enabled strategies for teaching and learning, including the possibility of more adaptive and personalized learning (Dooley \& Murphrey, 2000). Some studies suggested that online learning provides faculty with attractive options for increasing peer-to-instructor and peer-to-peer communications (Wasilik \& Bollinger, 2009). For instance, in an online, asynchronous forum, all students could be given an equal opportunity to communicate. This may especially benefit introverted students, secondlanguage students, or those who would have missed class conversations due to an absence (Hiltz et al., 2007). Finally, when considering online teaching, faculty may strongly consider whether their institution recognizes and rewards such efforts in the promotion and tenure process, teaching awards, course releases for development time, and/or financial stipends (Betts \& Heaston, 2014; Haber \& Mills, 2008; Hoyt \& Oviatt, 2013; Johnson et al., 2015). For many faculty members, the decision to teach online or not reflects how they perceive the return on investment (Wolcott $\&$ Betts, 1999).

\section{Factors that Discourage Online Teaching}

Discouraging factors play an especially important role in motivation because barriers perceived to be too burdensome have the potential to negate incentives that might otherwise encourage online teaching (Shea, 2007). Commonly reported themes in the literature included: faculty time and workload, technology issues, student engagement, course quality concerns, and fear or resistance to change. Key concerns include faculty members beliefs that teaching online requires more time than teaching face-to-face as well as concerns about the complexity of online teaching technologies (Berge, 2002; Berge et al., 2002; Lloyd et al., 2012; Mitchell et al., 2015; Wasilik \& Bollinger, 2009). Birch and Burnett (2009) recommended institutions take into consideration the time it takes academics to develop and maintain e-learning environments in performance reviews and in promotion interviews.

Other concerns included perceptions that the quality of online courses and the quality of student engagement are poor compared to face-to-face environments (Allen \& Seaman, 2015; Berge et al., 2002; Wasilik \& Bollinger, 2009). In a 2012 study, 66\% of surveyed faculty believed learning outcomes for online courses were inferior or somewhat inferior to traditional face-to-face courses and only $25 \%$ of faculty felt their institutions had good tools to assess the quality of online courses (Allen et al., 2012). Faculty may also fear a decrease in enjoyment from teaching if they believe that they will not be able to witness their impact students when they are teaching online (Bacow et al., 2012; Mitchell et al., 2015).

Finally, a factor discouraging faculty from teaching online may be an underlying fear or aversion to change. A survey found that $51 \%$ of faculty at two-year institutions were more fearful 
than excited about the growth of online learning, and $60 \%$ of faculty at four-year institutions reported feelings of fear (Allen et al., 2012). Mitchell et al. (2015) identified fear as a key source of faculty resistance to online teaching: they fear technology as too time-consuming, fear failure when learning a new way of teaching, or fear the loss of a comfortable and successful approach to teaching.

In summary, understanding what factors encourage or discourage online teaching is an important step for motivating faculty to teach online. This is especially true for liberal arts institutions who may experience resistance to online teaching from faculty who hold strong beliefs about teaching and value in-person relationships with students.

\section{Theoretical Framework}

The Decomposed Theory of Planned Behavior (DTPB) serves as a framework in this study to discuss faculty's planned decisions to teach online through an examination of three relevant psychological constructs. Taylor and Todd (1995) developed DTPB to better understand the determinants of technology usage for the effective deployment of resources in an organization. The DTPB supposes that intentional behavior is influenced by attitudinal beliefs, normative beliefs, and control beliefs.

The attitudinal beliefs component of the DTPB model describes perceptions of an innovative practice and examines the degree to which an individual supports the behavior under study (Taylor \& Todd, 1995). Attitudinal beliefs are examined through the dimensions of compatibility, perceived ease of use, and perceived usefulness. "Compatibility" describes how an innovative practice aligns with an individual's existing values, needs, and experiences. "Perceived ease of use" or "complexity" describes the perceived difficulty to understand, learn, or operate the components of an innovative practice. "Perceived usefulness" or "relative advantage" refers to the degree with which an innovative practice provides important benefits or is better than the current practice (Taylor \& Todd, 1995).

Normative beliefs are influenced by three dimensions: peers, superiors, and subordinates. Normative groups within an educational organization are comprised of "peers" (faculty), "superiors" (institutional leaders), and "subordinates" (students) (Taylor \& Todd, 1995). Control beliefs are affected by the three dimensions of self-efficacy, available resources, and available technology (Taylor \& Todd, 1995). "Self-efficacy" is an internal dimension related to one's perceived ability to be successful at a task. The dimensions of "available resources" such as time and money and "available technology" are considered "facilitating conditions" (Taylor \& Todd, 1995). Taylor and Todd note that the absence of facilitating conditions may present a barrier to usage but the presence of facilitating resources may not necessarily encourage usage.

\section{Methods}

This study utilized a convergent, parallel, mixed-methods design to gather data on faculty perceptions of online teaching and learning. A cross-sectional survey instrument collected distinct but complementary quantitative and qualitative data for a more complete understanding of the phenomenon (Creswell \& Plano Clark, 2011). 


\section{Participants and Context}

This study was implemented at a liberal arts university located in the Pacific Northwest portion of the United States serving around 3,300 students. Potential participants in this study included all faculty who had not completed the university's program to prepare faculty to teach online. Of the 320 faculty members invited to participate in this survey, 79 faculty submitted surveys for a response rate of $25 \%$. Table 1 shows the number of respondents in each division or school. The divisions of Social Science and Natural Science had the highest representation. Participants ranged from newly hired instructors to faculty with 40 years of experience at the university, as shown in Table 2 . The majority of participants were employed full time (91\%) as full or associate professors $(55.7 \%)$.

Table 1

Characteristics of Survey Participants: School/Division

\begin{tabular}{lll}
\hline School/Division & Frequency & Respondents \\
\hline Business & 9 & $11.4 \%$ \\
Humanities & 8 & $10.1 \%$ \\
Educ. \& Kinesiology & 2 & $2.5 \%$ \\
Natural Sciences & 18 & $22.8 \%$ \\
Nursing & 3 & $3.8 \%$ \\
Arts \& Communication & 12 & $15.2 \%$ \\
Social Sciences & 25 & $31.6 \%$ \\
Library & 2 & $2.5 \%$ \\
TOTAL & 79 & $100 \%$ \\
\hline
\end{tabular}

Table 2

Characteristics of Survey Participants: Years at Institution

\begin{tabular}{lll}
\hline Years & Frequency & Respondents \\
\hline $0-3$ & 17 & $21.5 \%$ \\
$4-7$ & 17 & $21.5 \%$ \\
$8-11$ & 14 & $17.7 \%$ \\
$12-15$ & 9 & $11.4 \%$ \\
$16-19$ & 10 & $12.7 \%$ \\
$20+$ & 12 & $15.2 \%$ \\
TOTAL & 79 & $100 \%$ \\
\hline
\end{tabular}

\section{Survey Instrument}

After a review of previous instruments to examine faculty's perceptions of e-learning (Ajjan \& Hartshorn, 2008; Dos Santos \& Okazaki, 2013), a new survey instrument was developed to answer the specific research questions in this study. Survey questions reflected factors identified in current research studies as well as the dimensions of the Decomposed Theory of Planned Behavior. To establish face validity for the survey instrument, feedback was gathered from (1) experts in the field of educational technology and (2) faculty currently participating in online teaching at the university under study. Survey question prompts and factors were revised multiple times to incorporate the recommendations of reviewers. The fourth and final version of the survey 
instrument contained three qualitative prompts and one quantitative question consisting of 21 individual factors. The full version of the instrument is provided in Appendix A and summarized below in Table 3. An online version of the survey was sent to all invited participants and paper copies of the survey were sent to participants who did not respond to the online survey within seven days.

Table 3

Overview of Survey Instrument Questions

\begin{tabular}{ll}
\hline Survey Question & Research Question \\
\hline $\begin{array}{l}\text { S1. What role do you think online learning should } \\
\text { have in the future of education at the university? }\end{array}$ & $\begin{array}{l}\text { RQ1. How do faculty perceive online teaching } \\
\text { and learning at the university? }\end{array}$ \\
$\begin{array}{l}\text { What do you see as potential strengths, weaknesses, } \\
\text { opportunities, and/or threats for online learning at the }\end{array}$ \\
$\begin{array}{l}\text { university? Please explain. }\end{array}$
\end{tabular}

S2. How do you view the idea of teaching online courses at the university? Would you consider

RQ1. How do faculty perceive online teaching teaching online? If so, when and why? Please and learning at the university? explain.

S3. What would it take for you to feel comfortable RQ1. How do faculty perceive online teaching teaching online at the university? What would be the and learning at the university? most important factors affecting your willingness to teach online? Please explain.

S4. Consider each of the factors listed below. Determine whether each factor would encourage, discourage, or not influence your decision (neither encourage nor discourage you) to teach online at the university. Then rate how important each factor would be on your personal decision to teach or not teach online.

\section{Data Analysis}

Creswell and Plano Clark (2011) recommend that researchers analyze the qualitative and quantitative strands of a convergent mixed method study separately before merging the results. Therefore, qualitative and quantitative data sets in this study were analyzed and presented separately to answer the research questions and then merged for discussion. A content analysis processes was utilized to describe faculty perceptions of online teaching (Rourke \& Anderson, 2004). Exploring underlying themes in participant responses, the researchers discussed beliefs which influence faculty behaviors. The lead researcher initially coded all the qualitative data for discrete concepts, which resulted in over 50 codes. Then the researcher grouped concepts into 15 categories, and consolidated the categories into six final themes. Detailed definitions of themes were created. A random sample of $25 \%$ of qualitative responses were coded independently by the first and the second researcher, based on the definitions of the themes.

In order to more effectively merge qualitative and quantitative data, responses were coded at the participant level. Initially, an agreement rate of $85.8 \%$ was achieved between two researchers with $100 \%$ agreement achieved after discussion. Theme definitions were refined for clarity at this point. Then the lead researcher coded the rest of the $75 \%$ of the responses based on refined 
definitions of the themes. Descriptive quantitative data analysis was employed to answer Research Question 2, including calculations of frequency and mean scores for 21 factors under evaluation. Descriptive statistics reported characteristics of the sample without making inferences about the sample's larger population (Creswell \& Clark, 2011).

\section{Results}

\section{Faculty perceptions of online teaching at a liberal arts university}

To answer the first research question, data from three open-ended survey questions asked participants:

1. What role do you think online learning should have in the future of education at [the university]? What do you see as potential strengths, weaknesses, opportunities, and/or threats for online learning at [the university]? Please explain.

2. How do you view the idea of teaching online courses at [the university]? Would you consider teaching online? If so, when and why? Please explain.

3. What would it take for you to feel comfortable teaching online at [the university]? What would be the most important factors affecting your willingness to teach online? Please explain.

Six themes surfaced in the qualitative data: (1) teaching values compatibility, (2) attractiveness to students, (3) regulation of online learning, (4) faculty resources, (5) personal influences, and (6) technology and infrastructure. After the identification of these themes, each set of participant responses was coded to identify what, if any, of the six themes were evident. Every participant discussed one or more of the six themes; the percentage of participants who discussed each theme is presented in Table 4 below.

Table 4

Frequency of Qualitative Themes

\begin{tabular}{lll}
\hline Qualitative Theme & $\begin{array}{l}\text { Frequency } \\
\text { (Number of } \\
\text { participants) }\end{array}$ & \% Participants \\
\hline Teaching values compatibility & 60 & $76 \%$ \\
Attractiveness to students & 57 & $72 \%$ \\
Regulation of online learning & 45 & $57 \%$ \\
Faculty resources & 44 & $56 \%$ \\
Personal influences & 42 & $53 \%$ \\
Technology and infrastructure & 27 & $34 \%$ \\
\hline
\end{tabular}




\section{Theme 1: Teaching Values Compatibility}

The most common theme that surfaced in participants' responses involved opinions about how "good teaching" should be delivered to students. This theme was evident in $76 \%$ of responses, including frequent mention of the importance of face-to-face learning, in-person communication, live interactivity, and the campus community as valued practices that online learning cannot provide. Many faculty participants believed that the university's distinctiveness is based in part on its ability to cultivate in-person relationships with students. One faculty member stated, "The promise we make potential [the university] students is that they will be known and will have a face to face encounter with their professors, will have the opportunity to meet with their professors." Another respondent emphasized the importance of the campus community saying, "A strength of [the university] is that the [university] learning experience includes 'campus life' and in-class personal interactions with students and faculty. Thus, a weakness of online learning would be the lack of the total experience."

Additionally, respondents had mixed feelings on the alignment of online teaching with their personal teaching values and the shared values of the institution. For instance, one faculty member stated, "Online courses assume that what we do in the classroom, face-to-face with students, can be replicated in an electronic format. It undervalues our art of teaching and I see it in direct conflict with our values as an institution." Concerns typically focused on how online learning might adversely affect the preservation of personal and institutional values, distinction, and strengths.

\section{Theme 2: Attractiveness to Students}

A prevalent theme in the qualitative data set, noted by $72 \%$ of respondents, was affirmation of practical reasons that students may be attracted to online learning. For instance, one participant stated, "Offering online courses over summer and [winter] makes sense because it allows students to earn credit while being away from campus." Some comments emphasized that online courses provide flexible learning options that meet the needs of a wider range of students, especially adult, military, working, or commuter students. One faculty member explained, "I think that online teaching offers the ability to reach non-traditional students and those who struggle to balance oncampus responsibilities and daily-life responsibilities." Additionally, multiple respondents felt that the university could attract or retain students by providing a wider variety of learning options to help them succeed and graduate. One faculty member said, "Online, particularly blended learning has the potential to enrich the experience AND possibly via a bridge course, help students catch up."

\section{Theme 3: Regulation of Online Learning}

Theme 3 broadly encompassed comments made by participants that online learning at the university would be acceptable only under certain conditions, and therefore it should be carefully regulated. This concept was present in $57 \%$ of responses through in statements that certain disciplines, courses, students, levels of learning, or terms are more appropriate for online learning than others are. One faculty member advocated for disciplinary restrictions stating, "I worry that by switching to teaching classes online we will be shortchanging students... online classes in the future should be offered in moderation, and only in certain disciplines. I do not think that mathematics and science courses should be taught online." This theme also included concerns about the quality and effectiveness of online courses, with many comments suggesting online courses should be regulated and monitored more closely than face-to-face courses. One faculty 
member claimed, "I think there needs to be more quality control of online courses. There needs to be more strict review of online and blended courses so that the academic rigor is equal to face-toface classes." Others were interested in "seeing evidence that students actually learn at least as much as in a regular format."

\section{Theme 4: Faculty Resources}

The fourth theme represented 56\% of responses and emphasized participants' desire for the university to invest resources into the successful development and teaching of online courses. For instance, one faculty member bluntly stated, "The only possible motivation for teaching an online course would be to have a much greater stipend and/or course release to make up for the huge amount of labor that is put into developing an online course." Some respondents emphasized the importance of training and support. One comment noted, "Faculty development would definitely be necessary, and the opportunity to work with a group of peers who are also experimenting with online teaching, so we would have a built-in support group to consult when issues arise." Interest and support for the university's online training program was high, and several faculty participants expressed enthusiasm for the opportunity to participate.

\section{Theme 5: Personal Influences}

The fifth qualitative theme, present in 53\% of responses, encompassing discussions of faculty's personal goals, situations, preferences, concerns, experiences, and interests as it affects online teaching. Personal influences included statements of personal dislike or attraction to online teaching, or general fears or concerns about one's personal ability to teach online. Comments within this theme were distinguished from concerns about online teaching's effectiveness, which were classified as a "teaching value compatibility" issues, or concerns about workload, which were classified as a "faculty resource" issues. Some comments categorize in this theme reflected personal preferences that would be difficult to address by institutional policies or planning. For instance, one faculty member humorously stated, "I would never feel comfortable teaching an online course because what I teach is old world - made up by people who take naps in the middle of the day."

\section{Theme 6: Technology and Infrastructure}

The final theme found in $34 \%$ of responses included a variety of comments on the importance of technology, infrastructure, and technical support. Concerns about technology ranged from vague fears to specific concerns. For instance, one faculty member stated, "There's a lot about the online space that simply isn't comfortable for me. I don't like managing technology, because I find it frustrating." Respondents also wanted the university to ensure adequate technical support was available to instructors and students who would be relying heavily on technology that must function well in order for online learning to be successful. Comments included statements such as, "All I can say is that extensive infrastructure and support are needed to make a success of such undertakings." This theme included concerns about the learning management system, which was the most frequent complaint expressed about technology.

In sum, participants in this study perceived online teaching at the university as attractive for students who may need nontraditional options for learning. In order to be successful, faculty respondents desired facilitative technology and infrastructure as well as faculty resources. However, these things alone may not be enough to motivate faculty participants to teach online. Personal influences and considerations also affected perceptions of online teaching and learning. 
Additionally, the teaching values of participants greatly influenced their perceptions of online teaching. Many respondents believed that online learning at the institution needed to be regulated to safeguard course quality and to ensure it was only permitted in specific circumstances. Overall, many faculty participants were skeptical of online learning but willing to consider it under the right circumstances.

\section{Table 5}

Frequency of Factors, Sorted by \% of Total Influence

\begin{tabular}{|c|c|c|c|}
\hline Factor & Encouraged & Discouraged & $\begin{array}{l}\text { Total \% } \\
\text { Influenced }\end{array}$ \\
\hline $\begin{array}{l}\text { Suitability of online teaching and learning for } \\
\text { course needs }\end{array}$ & $54 \%$ & $39 \%$ & $93 \%$ \\
\hline Instructional support provided by the institution & $66 \%$ & $24 \%$ & $90 \%$ \\
\hline Student engagement in online courses & $31 \%$ & $59 \%$ & $90 \%$ \\
\hline $\begin{array}{l}\text { Time available for online course development and } \\
\text { training }\end{array}$ & $35 \%$ & $54 \%$ & $89 \%$ \\
\hline $\begin{array}{l}\text { Reflecting on current teaching practices and } \\
\text { exploring new ways of teaching }\end{array}$ & $61 \%$ & $25 \%$ & $86 \%$ \\
\hline $\begin{array}{l}\text { Technology available for teaching and learning } \\
\text { online }\end{array}$ & $59 \%$ & $25 \%$ & $84 \%$ \\
\hline Time and effort required to teach online & $20 \%$ & $63 \%$ & $83 \%$ \\
\hline Accommodating a wider variety of students & $72 \%$ & $9 \%$ & $81 \%$ \\
\hline Online learning's alignment to institutional identity & $30 \%$ & $36 \%$ & $66 \%$ \\
\hline Personal schedule flexibility for instructors & $69 \%$ & $8 \%$ & $77 \%$ \\
\hline $\begin{array}{l}\text { Technical support for instructors provided by the } \\
\text { institution }\end{array}$ & $65 \%$ & $10 \%$ & $75 \%$ \\
\hline $\begin{array}{l}\text { Additional compensation for online course } \\
\text { development and training }\end{array}$ & $67 \%$ & $7 \%$ & $74 \%$ \\
\hline $\begin{array}{l}\text { Opportunity for improved proficiency with } \\
\text { instructional technologies }\end{array}$ & $64 \%$ & $8 \%$ & $72 \%$ \\
\hline Current skills with instructional technology & $43 \%$ & $23 \%$ & $67 \%$ \\
\hline Student retention in online classes & $21 \%$ & $43 \%$ & $64 \%$ \\
\hline Option to teach online during all academic terms & $36 \%$ & $23 \%$ & $59 \%$ \\
\hline Influence of students & $42 \%$ & $12 \%$ & $54 \%$ \\
\hline $\begin{array}{l}\text { Past personal experiences with online teaching } \\
\text { and/or learning }\end{array}$ & $21 \%$ & $28 \%$ & $49 \%$ \\
\hline Prior experience teaching a blended course & $25 \%$ & $10 \%$ & $35 \%$ \\
\hline Influence of colleagues & $16 \%$ & $13 \%$ & $29 \%$ \\
\hline Influence of department leadership & $23 \%$ & $6 \%$ & $29 \%$ \\
\hline
\end{tabular}




\section{Reported Factors that Affect Faculty Members' Decisions to Teach or Not Teach Online}

Analysis of the quantitative data in this study focused on how faculty respondents classified 21 unique factors as encouraging, discouraging, or not influential in their decision to teach online. More than $50 \%$ of participants reported 17 factors as influential to their decision to teach or not teach online. Table 5 above shows the frequency of factors selected by survey respondents. The top five factors selected included "suitability of online teaching and learning for course needs" that was considered influential by $93 \%$ of faculty participants; "instructional support provided by the institution" and "student engagement in online courses" were influential to $90 \%$ of respondents; "time available for online course development and training" was influential for $89 \%$ of respondents; and, "reflecting on current teaching practices and exploring new ways of teaching" was influential to $86 \%$ of respondents.

\section{Discussion}

Overall, the results of this mixed-methods study showed strong agreement between the quantitative and qualitative data. To support the convergence of data, the discussion of findings is organized around six key themes from the qualitative data. Each section includes a joint discussion of the quantitative and qualitative data (Creswell \& Plano Clark, 2011). This approach was selected because the qualitative themes provided a useful structure for considering both datasets, prior research, and the DTPB from a holistic perspective. The DTPB provided a framework for discussing the results of this study by considering the influence of faculty participants' attitudes, subjective norms, and perceived behavioral control on their willingness to teach online in the future.

\section{Attractiveness to Students}

"Attractiveness to students" was a common theme in the qualitative data that demonstrated the influence of students on the faculty members' decisions to teach or not teach online. "Accommodating a wider variety of students" ( $81 \%$ total influence), "student engagement in online courses" (90\%), "student retention in online courses" (64\%) and the "influence of students" (54\%) were all factors identified as influential in the quantitative portion of the survey. This qualitative theme and related quantitative factors can be attributed to two constructs of the DTPB: (1) subjective norms as seen through the dimension "influence of students" and (2) attitude as seen through the dimension "perceived usefulness."

Prior research studies have demonstrated the influence of students on faculty members' decisions making. Studies by Maguire (2005) and Betts and Heaston (2014) both noted the importance of student pressure on faculty members' decisions to participate in distance education. Clark (1997) concluded that faculty members at midlevel American liberal arts institutions particularly value their relationships with students, and this study provides further evidence of the influence of students.

The quantitative factor "accommodating a wider variety of students" and the qualitative theme "attractiveness to students" were interpreted as similar to the DTPB dimension "perceived usefulness" as the anytime, anywhere nature of online education is useful for many learners. Faculty participants in this study acknowledged the potential benefits of online learning for students, and this encouraged participants to consider teaching online. The possibility of increasing access to higher education for a wider audience of learners was a strong incentive evident in this 
study and noted in several prior research studies (Allen \& Seaman, 2008; Dooley \& Murphrey, 2000; Maguire, 2005; Shea, 2007). Participants in this study described benefits to retention, recruitment, and competitiveness, especially for nontraditional students (i.e., adult, military, working, or commuter students).

\section{Teaching Value Compatibility}

Despite the attractiveness of online learning for some students, many faculty respondents resisted the idea because they believed it conflicted with their teaching values. This theme was related to the DTPB's attitudinal dimension "compatibility," which describes whether an innovative practice aligns with existing values, needs, and experiences. Approximately $66 \%$ of respondents claimed online learning's alignment to institutional values was influential in their decision to teach or not teach online, and institutional values were frequently discussed in written responses. Prior research supports these findings. Mitchell et al. (2015) found that faculty members resist initiatives that appear to threaten their values. Berge (1998) identified cultural barriers (the institutional culture; i.e., the beliefs, values, expectations, and norms of an organization) as the largest category of barriers to online teaching. Zhen et al. (2008) also found that faculty members' teaching philosophies were a significant variable in their discrete decision model for online teaching. Haber and Mills (2008) stated that one of the greatest barriers to online instruction was concerns about the lack of interaction and communication between faculty members and students.

The comments of faculty respondents in this study demonstrated a strong desire to preserve traditional in-person student relationships. To encourage faculty members to participate in online learning, faculty may need reassurance and support to help them understand how to preserve teaching values in the online environment. Professional development efforts can support faculty members through modeling online course design (Borup \& Evmenova, 2019) and instructional strategies compatible with their teaching values and teaching approaches (Richardson et al., 2020).

\section{Regulation of Online Learning}

Concerns about the compatibility of online teaching with deeply held teaching values may have contributed to the emergence of the third theme, "Regulation of online learning." The "suitability of online teaching and learning for course needs" was reported as influential by $93 \%$ of survey respondents. These ideas were interpreted as linked to the DTPB's attitudinal belief structure, particularly the dimensions of perceived usefulness and compatibility. Many faculty respondents expressed concerns that online learning was bad for the institution, their program, students, or themselves. As noted in the literature review, Allen and Seaman (2015) found that just $28 \%$ of faculty respondents in surveyed institutions accepted the value and legitimacy of online education.

The findings of this study are consistent with prior research identifying faculty members' concerns about online course quality. Subsequently, many respondents in this study wanted to regulate online learning by placing restrictions on what disciplines, courses, students, levels of learning, or terms would be allowed for online learning. Regulation also involved closely monitoring online courses for quality. Respondents wanted new institutional regulations for online learning to be in place via specific course development and review processes. Betts and Heaston (2014) also identified the quality of online courses as a primary concern of faculty members at their institution. 
The results of a recent federal funded study suggested that the indicators of online course quality (i.e., learner support, course design and organization, content design and delivery, interactivity, and assessment) had significant relationships with students' learning, satisfaction, and academic performance in online courses at a higher educational institution (Joosten \& Cusatis, 2019). Faculty members' desires to regulate and restrict online learning in order to preserve the quality of education at an institution is an area that could be investigated in more detail in the future. Introducing faculty to the use of online course evaluation instruments to guide course development and review processes (Baldwin \& Ching, 2019; Baldwin et al., 2018) and establish a course review process at the institution level may help address faculty members' concerns over online course quality.

\section{Technology and Infrastructure}

Another theme identified in the qualitative data of this study highlighted faculty participants' concerns about the technology and infrastructure needed to teach online. "Technology available for teaching and learning" was identified as important to $84 \%$ of survey respondents. This theme aligned closely with the DTPB dimension "available technologies", within the control belief structure. Technology is an essential aspect of online teaching. Faculty members' concerns about technology for online teaching are well documented in prior research (Berge et al., 2002; Hiltz et al., 2007; Mitchell et al., 2015; Shea, 2007; Wingo et al., 2017). Maguire's (2005) review of the literature found that a lack of technical support, lack of training, and inadequate infrastructure, hardware, and software were some of the most frequently cited barriers to online teaching. Appropriate technology for teaching is foundational for faculty member participation in online teaching.

\section{Faculty Resources}

Faculty members want their institutions to provide effective technology resources and support, but other resources are also important. In qualitative responses, faculty participants requested a variety of resources from the institution, including pedagogical training, time, and compensation. The quantitative data echoed these requests: "instructional support provided by the institution" (90\%) "time available for online course development and training" (89\%), and "additional compensation" (74\%). These factors were classified as similar to the DTPB dimension "available resources" in the construct "control beliefs." As with technology, faculty members must be convinced that their institution will provide them with appropriate resources and training before they will consider investing time and effort into experimenting with online teaching. Since "selfefficacy" is a dimension of "control beliefs," providing online teacher training might help institutions to increase faculty member's confidence in their ability to teach online.

Recent studies have provided guidelines on best practices of online teaching (e.g., facilitation strategies in Martin et al., 2020) and effective professional development approaches for online teaching for higher education faculty (e.g., Borup \& Evmenova, 2019; Northcote et al., 2019; Olesova \& Campbell, 2019; Richardson et al., 2020). Prior research has documented the importance of various institutional rewards and resources on faculty members' consideration of online teaching (Betts \& Heaston, 2014; Herman, 2012; Hoyt \& Oviatt, 2013; Maguire, 2005; Wasilik \& Bollinger, 2009). 


\section{Personal Influences}

Personal goals, situations, preferences, concerns, experiences, and interests can influence faculty's perceptions of online teaching. Personal influences have an obvious effect on attitudes, but they are also strongly associated with the self-efficacy dimension of control beliefs in the DTPB. "Current skills with instructional technology" (67\%), "past personal experiences with online teaching and learning" (49\%), and "prior experience teaching blended courses" (35\%) were survey factors associated with self-efficacy. Of these factors, "current skills with technology" was perceived as the most influential to participants in this study. This aspect of self-efficacy suggests that faculty members' perceptions of their current technical skills do affect their willingness to teach online.

"Reflecting on current teaching practices and exploring new ways of teaching" was influential to $86 \%$ of faculty participants in this study. This factor relates to motivation and pleasure from learning new skills. In Maguire's (2005) review of the literature, she concluded that intrinsic motivators, such as intellectual challenge and personal motivation to use technology, were stronger than extrinsic motivators for online teaching. There is strong evidence in prior research that faculty members may be motivated by the opportunity for professional, technical, or creative challenges (Hiltz et al., 2007; Lloyd et al., 2012; Maguire, 2005).

\section{Recommendations and Limitations}

Future research on this topic could help liberal arts institutions that want to grow their online offerings but need evidence-based strategies for recruiting faculty members to teach online. First, a national study of the perceptions of online teaching among liberal arts faculty across the U.S. would contribute broader insight into the perceptions of this population. A study on liberal arts faculty members' readiness to teach online that focuses on perceptions of ability and confidence would also be a useful extension of research (Martin et al., 2019). Second, the survey instrument used in this study could be altered for closer alignment to the dimensions of the DTPB. In this study, the DTPB was used as a framework for data analysis and discussion of findings. However, future researchers may consider designing a research study or instrument exclusively focused on the dimensions of this framework. An instrument focused specifically on the dimensions of the DTPB would allow for further testing of the theory and greater discussion of the DTPB constructs as determinants of planned behavior related to faculty participation in online teaching.

Subsequent research using the DTPB to study faculty members' participation in online teaching could reexamine whether the dimensions of peer influence and superior influence are perceived as influential in other populations. This study found the influence of peers and superiors were not influential for participants; however, additional testing is needed to determine whether this is an isolated instance or evidence of a larger phenomenon among faculty members at liberal arts institutions.

A limitation of this study is the nature of self-reporting opinions, perceptions, and anticipated behaviors. Self-reported data may not accurately predict or explain actual behaviors, which could affect the validity of a study's results. In addition, the low response rate of the survey ( $25 \%$ in this study) presents another limitation of this study. The potential of non-response bias may invalidate study results. It should be noted that participants in this study did not reflect the exact demographics of the larger faculty population. For instance, the participant sample contained larger numbers of natural sciences and social sciences faculty members than would be represented 
in the entire population. Therefore, the perceptions of some faculty groups may be overrepresented while other groups may be underrepresented.

\section{Conclusion}

This study examined how faculty members perceived online teaching at a midsized liberal arts university in order to increase faculty acceptance and participation in online teaching at that university. The findings of this research expanded previous research on faculty perceptions of online teaching by studying faculty at a midsized liberal arts university in the Pacific Northwest. A mixed-methods approach to the investigation resulted in strong agreement around six key themes and 17 influential factors. Overall, faculty participants at this liberal arts university appeared encouraged or discouraged from online teaching by factors that were noted in prior research and supported by the theoretical framework of the DTPB.

Faculty participants acknowledged that online learning could increase educational access for students, especially nontraditional student populations. This influential factor was supported in prior research and reflected the influence of students and the perceived usefulness of online learning, two dimensions of the DTPB. Faculty respondents in this study also discussed concerns of whether online learning aligned to personal teaching values and the values of their institution, which reflected the DTPB dimension of compatibility. In addition to concerns about compatibility, faculty participants expressed a need for robust technology, technical and instructional support, development time, training, and other related resources. These findings are similar to prior research and represented in the DTPB through the dimensions of facilitating technology and resources. Faculty respondents in this study also expressed a desire to carefully regulate online learning at the institution through a variety of conditions and restrictions. Faculty members' requests to regulate online learning could indicate a desire to preserve teaching values and ameliorate fears of change, which connected to the DTPB dimensions of compatibility and perceived usefulness. 


\section{References}

Ajjan, H., \& Hartshorn, R. (2008). Investigating faculty decisions to adopt Web 2.0 technologies: Theory and empirical tests. The Internet and Higher Education, 11(2), 71-80.

Allen, I. E., \& Seaman, J. (2008). Staying the course: Online education in the United States, 2008. Sloan-C. https://www.onlinelearningsurvey.com/reports/staying-the-course.pdf

Allen, I. E., \& Seaman, J. (2015). Grade level: Tracking online education in the United States.

Babson Survey Research Group and Quahog Research Group. http://www.onlinelearningsurvey.com/reports/gradelevel.pdf

Allen, I. E., Seaman, J., Lederman, D., \& Jaschik, S. (2012). Conflicted: Faculty and online education. Inside Higher Ed, Babson Survey Research Group and Quahog Research Group. https://onlinelearningsurvey.com/reports/conflicted.pdf

Bacow, L. S., Bowen, W. G., Guthrie, K. M., Lack, K. A., \& Long, M. P. (2012). Barriers to adoption of online learning systems in US higher education. Ithaka $\mathrm{S}+\mathrm{R}$.

Baker, V., \& Baldwin, R. (2015). A case study of liberal arts colleges in the 21st century: Understanding organizational change and evolution in higher education. Innovative Higher Education, 40(3), 247-261.

Baldwin, S., \& Ching, Y.-H. (2019). An online course design checklist: Development and users' perceptions. Journal of Computing in Higher Education, 31(1), 156-172. https://doi.org/10.1007/s12528-018-9199-8

Baldwin, S., Ching, Y.-H., \& Hsu, Y.-C. (2018). Online course design in higher education: A review of national and statewide evaluation instruments. TechTrends, 62(1), 46-57. doi:10.1007/s11528-017-0215-z

Berge, Z. L. (1998). Barriers to online teaching in post-secondary institutions: Can policy changes fix it? Online Journal of Distance Learning Administration, 1(2). https://www.westga.edu/ distance/ojdla/summer12/berge12.pdf

Berge, Z. L. (2002). Obstacles to distance training and education in corporate organizations. Journal of Workplace Learning, 14(5), 182-189.

Berge, Z. L., Muilenburg, L. Y., \& Haneghan, J. V. (2002). Barriers to distance education and training: Survey results. The Quarterly Review of Distance Education, 3(4), 409-418.

Betts, K., \& Heaston, A. (2014). Build it but will they teach? Strategies for increasingfaculty participation \& retention in online \& blended education. Online Journal ofDistance Learning Administration, 17(2).

https://www.westga.edu/ distance/ojdla/summer172/betts_heaston172.html

Birch, D., \& Burnett, B. (2009). Bringing academics on board: Encouraging institution-wide diffusion of e-learning environments. Australasian Journal of Educational Technology, 25(1), 117-134.

Borup, J., \& Evmenova, A.S. (2019). The effectiveness of professional development in overcoming obstacles to effective online instruction in a college of education. Online Learning, 23(2), 1-20. doi:10.24059/olj.v23i2.1468 
Clark, B. (1987). The academic life: Small worlds, different worlds. Carnegie Foundation for the Advancement of Teaching.

Clark, B. (1997). Small worlds, different worlds: The uniquenesses and troubles of American academic professions. Daedalus, 126(4), 21-42.

Creswell, J. W., \& Plano Clark, V. L. (2011). Designing and conducting mixed methods research. SAGE Publications.

Deneen, P. (2014). After the interregnum. Academic Questions, 27(4), 368-375.

Dooley, K. E., \& Murphrey, T. P. (2000). How the perspectives of administrators, faculty, and support units impact the rate of distance education adoption. Online Journal of Distance Learning Administration, 3(4). https://www.westga.edu/ distance/ojdla/winter34/dooley34.html

Dos Santos. L. M. R., \& Okazaki, S. (2013). Understanding e-learning adoption among Brazilian universities: An application of the decomposed theory of planned behavior. Journal of Educational Computing Research, 49(3), 363-379.

Haber, J., \& Mills, M. (2008). Perceptions of barriers concerning effective online teaching and policies: Florida community college faculty. Community College Journal of Research and Practice, 32(4-6), 266-283.

Herman, J. (2013). Faculty incentives for online course design, delivery, and professional development. Innovative Higher Education, 38(5), 397-410.

Hiltz, S. R., Kim, E., \& Shea, P. (2007). Faculty motivators and de-motivators for teaching online: Results of focus group interviews at one university. 40th Annual Hawaii international Conference on System Sciences, 2007. https://pdfs.semanticscholar.org/465c/f6ee0e14baada609f1e4abc2c87b1e3a87f1.pdf

Hoyt, J. E., \& Oviatt, D. (2013). Governance, faculty incentives, and course ownership in online education at doctorate-granting universities. American Journal of Distance Education, 27(3), 165-178.

Husmann, D. E., \& Miller, M. T. (1999). Faculty incentives to participate in distance education. Michigan Community College Journal: Research \& Practice, 5(2), 35-42. https://www.learntechlib.org/p/88741/

Johnson, R., Stewart, C., \& Bachman, C. (2015). What drives students to complete online courses? What drives faculty to teach online? Validating a measure of motivation orientation in university students and faculty. Interactive Learning Environments, 23(4), 528-543.

Joosten, T., \& Cusatis, R. (2019). A cross-institutional study of instructional characteristics and student outcomes: Are quality indicators of online courses able to predict student success? Online Learning, 23(4), 354-378. doi: 10.24059/olj.v23i4.1432

Lloyd, S., Byrne, M., \& McCoy, T. (2012). Faculty-perceived barriers of online education. MERLOT Journal of Online Learning and Teaching, 8(1). https://jolt.merlot.org/vol8no1/1loyd_0312.pdf 
Maguire, L. L. (2005). Literature review-faculty participation in online distance education: Barriers and motivators. Online Journal of Distance Learning Administration, 8(1). https://www.westga.edu/ distance/ojdla/spring81/maguire81.htm

Martin, F., Budhrani, K., \& Wang, C. (2019). Examining faculty perception of their readiness to teach online. Online Learning, 23(3), 97-119. doi: 10.24059/olj.v23i3.1555

Martin, F., Wang, C., \& Sadaf, A. (2020). Facilitation matters: Instructor perception of helpfulness of facilitation strategies in online courses. Online Learning, 24(1), 28-49. https://doi.org/10.24059/olj.v24i1.1980

Mitchell, L. D., Parlamis, J. D., \& Claiborne, S. A. (2015). Overcoming faculty avoidance of online education: From resistance to support to active participation. Journal of Management Education, 39(3), 350-371.

Northcote, M., Gosselin, K. P., Kilgour, P., Reynaud, D., \& McLoughlin, C. (2019). A professional learning program for novice online teachers using threshold concepts. Online Learning, 23(4), 336-353. doi: 10.24059/olj.v23i4.1573

Olesova, L., \& Campbell, S. (2019). The impact of the cooperative mentorship model on faculty preparedness to develop online courses. Online Learning, 23(4), 192-213. doi:10.24059/olj.v23i4.2089

Richardson, J. W., Hollis, E., Pritchard, M., \& Lingat, J. E. M. (2020). Shifting teaching and learning in online learning spaces: An investigation of a faculty online teaching and learning initiative. Online Learning, 24(1), 67-91. https://doi.org/10.24059/olj.v24i1.1629

Rourke, L., \& Anderson, T. (2004). Validity in quantitative content analysis. Educational Technology Research and Development, 52(1), 5-18.

Seaman, J. E., Allen, I. E., \& Seaman, J. (2018). Grade increase: Tracking distance education in the United States. Babson Survey Research. http://www.onlinelearningsurvey.com/highered.html

Schopieray, S. E. (2006). Understanding faculty motivation to teach online courses (Publication 305307371) [Doctoral dissertation, Michigan State University]. ProQuest Dissertations \& Theses Global.

Shea, P. (2007). Bridges and barriers to teaching online college courses: A study of experienced online faculty in thirty-six colleges. Journal of Asynchronous Learning Networks, 11(2), 73128.

Taylor, S., \& Todd, P. A. (1995). Understanding information technology usage: A test of competing models. Information Systems Research, 6(2), 144-176.

Thompson, C. (2015). On the decline and fall of the liberal arts. Academic Questions, 28(4), $417-427$.

Vivolo, J. (2016). Understanding and combating resistance to online learning. Science Progress, 99(4), 399-412.

Wasilik, O., \& Bollinger, D. (2009). Faculty satisfaction in the online environment: An institutional study. The Internet and Higher Education, 12(3), 173-178. 
Wells, C. A. (2016). A distinctive vision for the liberal arts: General education and the flourishing of Christian higher education. Christian Higher Education, 15(1/2), 84-94.

Wingo,N. P., Ivankova, N. V., \& Moss, J. A. (2017) Faculty perceptions about teaching online: Exploring the literature using the technology acceptance model as an organizing framework. Online Learning, 21(1), 15-35. doi: 10.10.24059/olj.v21i1.761

Wolcott, L. L., \& Betts, K. S. (1999). What's in it for me? Incentives for faculty participation in distance education. Journal of Distance Education, 14(2), 34-49.

Zhen, Y., Garthwait, A., \& Pratt, P. (2008). Factors affecting faculty members' decision to teach or not to teach online in higher education. Online Journal of Distance Learning Administration, 11(3). https://www.westga.edu/ distance/ojdla/fall113/zhen113.html 


\section{Appendix A}

\section{Faculty Survey: Online Teaching Version 4}

Please consider the following questions and provide as much detail as possible to help us understand your perceptions and perspectives related to online teaching and learning at the university.

1. What role do you think online learning should have in the future of education at the university? What do you see as potential strengths, weaknesses, opportunities, and/or threats for online learning at the university? Please explain.

2. How do you view the idea of teaching online courses at the university? Would you consider teaching online? If so, when and why? Please explain.

3. What would it take for you to feel comfortable teaching online at the university? What would be the most important factors affecting your willingness to teach online? Please explain.

4. Consider each of the factors listed below. Determine whether each factor would encourage, discourage, or not influence your decision (neither encourage nor discourage you) to teach online at the university. Then rate how important each factor would be on your personal decision to teach or not teach online.

\begin{tabular}{|l|l|l|}
\hline $\begin{array}{l}\text { Does this factor would encourage, discourage, } \\
\text { or not influence your decision (neither } \\
\text { encourage nor discourage you) to teach online } \\
\text { at the university? How important each factor } \\
\text { would be on your personal decision to teach or } \\
\text { not teach online? }\end{array}$ & $\begin{array}{l}\text { Does this factor } \\
\text { encourage, discourage, } \\
\text { or not influence your } \\
\text { decision to teach } \\
\text { online? (Encouraging, } \\
\text { Discouraging, Not } \\
\text { Influential) }\end{array}$ & $\begin{array}{l}\text { How important is this factor } \\
\text { in your decision to teach } \\
\text { online? (Slightly important, } \\
\text { Somewhat important, Fairly } \\
\text { important, Very important) }\end{array}$ \\
\hline $\begin{array}{l}\text { Online learning's alignment to institutional } \\
\text { identity (i.e., consideration for the mission, } \\
\text { vision, and values of the university) }\end{array}$ & & \\
\hline $\begin{array}{l}\text { Suitability of online teaching and learning for } \\
\text { course needs } \text { (i.e., a good fit for course content, } \\
\text { methods, discipline, etc.) }\end{array}$ & & \\
\hline $\begin{array}{l}\text { Reflecting on current teaching practices and } \\
\text { exploring new ways of teaching (i.e., evaluating } \\
\text { and updating instructional strategies and } \\
\text { content) }\end{array}$ & & \\
\hline $\begin{array}{l}\text { Time available for online course development } \\
\text { and training (i.e., priority for this among other } \\
\text { commitments) }\end{array}$ & & \\
\hline $\begin{array}{l}\text { Option to teach online during all academic } \\
\text { terms (i.e., current practices limit online } \\
\text { courses to j-term and summer term) }\end{array}$ & & \\
\hline
\end{tabular}




\begin{tabular}{|l|l|l|}
\hline $\begin{array}{l}\text { Does this factor would encourage, discourage, } \\
\text { or not influence your decision (neither } \\
\text { encourage nor discourage you) to teach online at } \\
\text { the university? How important each factor } \\
\text { would be on your personal decision to teach or } \\
\text { not teach online? }\end{array}$ & $\begin{array}{l}\text { Does this factor } \\
\text { encourage, discourage, } \\
\text { or not influence your } \\
\text { decision to teach } \\
\text { online? (Encouraging, } \\
\text { Discouraging, Not } \\
\text { Influential) }\end{array}$ & $\begin{array}{l}\text { How important is this factor } \\
\text { in your decision to teach } \\
\text { online? (Slightly important, } \\
\text { Somewhat important, Fairly } \\
\text { important, Very important) }\end{array}$ \\
\hline $\begin{array}{l}\text { Past personal experiences with online teaching } \\
\text { and/or learning }\end{array}$ & & \\
\hline $\begin{array}{l}\text { Prior experience teaching a blended course (i.e., } \\
\text { skills and confidence from teaching a } \\
\text { blended course before teaching fully online) }\end{array}$ & & \\
\hline $\begin{array}{l}\text { Time and effort required to teach online (i.e., } \\
\text { comparability of face-to-face and online } \\
\text { teaching commitments }\end{array}$ & & \\
\hline $\begin{array}{l}\text { Instructional support provided by the institution } \\
\text { (i.e., training, instructional design, peer } \\
\text { mentoring) }\end{array}$ & & \\
\hline $\begin{array}{l}\text { Personal schedule flexibility for instructors (i.e., } \\
\text { the ability to teach anytime or anyplace and } \\
\text { accommodate other restrictions on availability) }\end{array}$ & & \\
\hline
\end{tabular}

\begin{tabular}{|l|l|l|}
\hline $\begin{array}{l}\text { Does this factor would encourage, discourage, } \\
\text { or not influence your decision (neither } \\
\text { encourage nor discourage you) to teach online at } \\
\text { the university? How important each factor } \\
\text { would be on your personal decision to teach or } \\
\text { not teach online? }\end{array}$ & $\begin{array}{l}\text { Does this factor } \\
\text { encourage, discourage, } \\
\text { or not influence your } \\
\text { decision to teach } \\
\text { online? (Encouraging, } \\
\text { Discouraging, Not } \\
\text { Influential) }\end{array}$ & $\begin{array}{l}\text { How important is this factor } \\
\text { in your decision to teach } \\
\text { online? (Slightly important, } \\
\text { Somewhat important, Fairly } \\
\text { important, Very important) }\end{array}$ \\
\hline $\begin{array}{l}\text { Accommodating a wider variety of students } \\
\text { i.e., increasing access for students who may not } \\
\text { be able to enroll in existing campus-based } \\
\text { options) }\end{array}$ & $\begin{array}{l}\text { Discouraging, Not } \\
\text { Influential) }\end{array}$ & $\begin{array}{l}\text { Somewhat important, Fairly } \\
\text { important, Very important) }\end{array}$ \\
\hline $\begin{array}{l}\text { Student engagement in online courses (i.e.,how } \\
\text { active students are in the learning } \\
\text { experience and the quality of interpersonal } \\
\text { interactions) }\end{array}$ & $\begin{array}{l}\text { (Encouraging, } \\
\text { Influential) }\end{array}$ & $\begin{array}{l}\text { (Slightly important, } \\
\text { Somewhat important, Fairly } \\
\text { important, Very important) }\end{array}$ \\
\hline
\end{tabular}




\begin{tabular}{|l|l|l|}
\hline Student retention in online classes & $\begin{array}{l}\text { (Encouraging, } \\
\text { Discouraging, Not } \\
\text { Influential) }\end{array}$ & $\begin{array}{l}\text { (Slightly important, } \\
\text { Somewhat important, Fairly } \\
\text { important, Very important) }\end{array}$ \\
\hline $\begin{array}{l}\text { Influence of students (i.e., student demand or } \\
\text { preferences for specific instructional formats) }\end{array}$ & $\begin{array}{l}\text { (Encouraging, } \\
\text { Discouraging, Not } \\
\text { Influential) }\end{array}$ & $\begin{array}{l}\text { (Slightly important, } \\
\text { Somewhat important, Fairly } \\
\text { important, Very important) }\end{array}$ \\
\hline $\begin{array}{l}\text { Influence of colleagues (i.e peer attitudes } \\
\text { regarding teaching online courses) }\end{array}$ & $\begin{array}{l}\text { (Encouraging, } \\
\text { Discouraging, Not } \\
\text { Influential) }\end{array}$ & $\begin{array}{l}\text { (Slightly important, } \\
\text { Somewhat important, Fairly } \\
\text { important, Very important) }\end{array}$ \\
\hline $\begin{array}{l}\text { Influence of university, division, school, or } \\
\text { department leadership (i.e., encouragement } \\
\text { or discouragement to teach online courses) }\end{array}$ & $\begin{array}{l}\text { (Encouraging, } \\
\text { Discouraging, Not } \\
\text { Influential) }\end{array}$ & $\begin{array}{l}\text { Somewhat important, Fairly } \\
\text { important, Very important) }\end{array}$ \\
\hline
\end{tabular}

\begin{tabular}{|l|l|l|}
\hline $\begin{array}{l}\text { Does this factor would encourage, discourage, } \\
\text { or not influence your decision (neither } \\
\text { encourage nor discourage you) to teach online at } \\
\text { the university? How important each factor } \\
\text { would be on your personal decision to teach or } \\
\text { not teach online? }\end{array}$ & $\begin{array}{l}\text { Does this factor } \\
\text { encourage, discourage, } \\
\text { or not influence your } \\
\text { decision to teach } \\
\text { online? (Encouraging, } \\
\text { Discouraging, Not } \\
\text { Influential) }\end{array}$ & $\begin{array}{l}\text { How important is this factor } \\
\text { in your decision to teach } \\
\text { online? (Slightly important, } \\
\text { Somewhat important, Fairly } \\
\text { important, Very important) }\end{array}$ \\
\hline $\begin{array}{l}\text { Additional compensation for online course } \\
\text { development and training }\end{array}$ & & \\
\hline $\begin{array}{l}\text { Current skills with instructional technology (i.e., } \\
\text { your confidence in your ability to learn } \\
\text { and use instructional technologies) }\end{array}$ & & \\
\hline $\begin{array}{l}\text { Opportunity for improved proficiency with } \\
\text { instructional technologies (i.e., learning how } \\
\text { to better use Sakai, online video, etc.) }\end{array}$ & & \\
\hline $\begin{array}{l}\text { Technical support for instructors provided by } \\
\text { the institution (i.e., training, instructional } \\
\text { technologies) }\end{array}$ & & \\
\hline $\begin{array}{l}\text { Technology available for teaching and learning } \\
\text { online (i.e., adequate software, tools, and } \\
\text { technology infrastructure for successful } \\
\text { teaching and learning online) }\end{array}$ & & \\
\hline
\end{tabular}

Thank you for participating in this survey! Your time and thoughts are greatly appreciated! If there is anything else you'd like to share on the topic of online teaching and learning, please do so in the space below. 